\title{
Cell Culture Protocols, HeLa and CHO cells Woods Hole Physiology Course, 2006
}

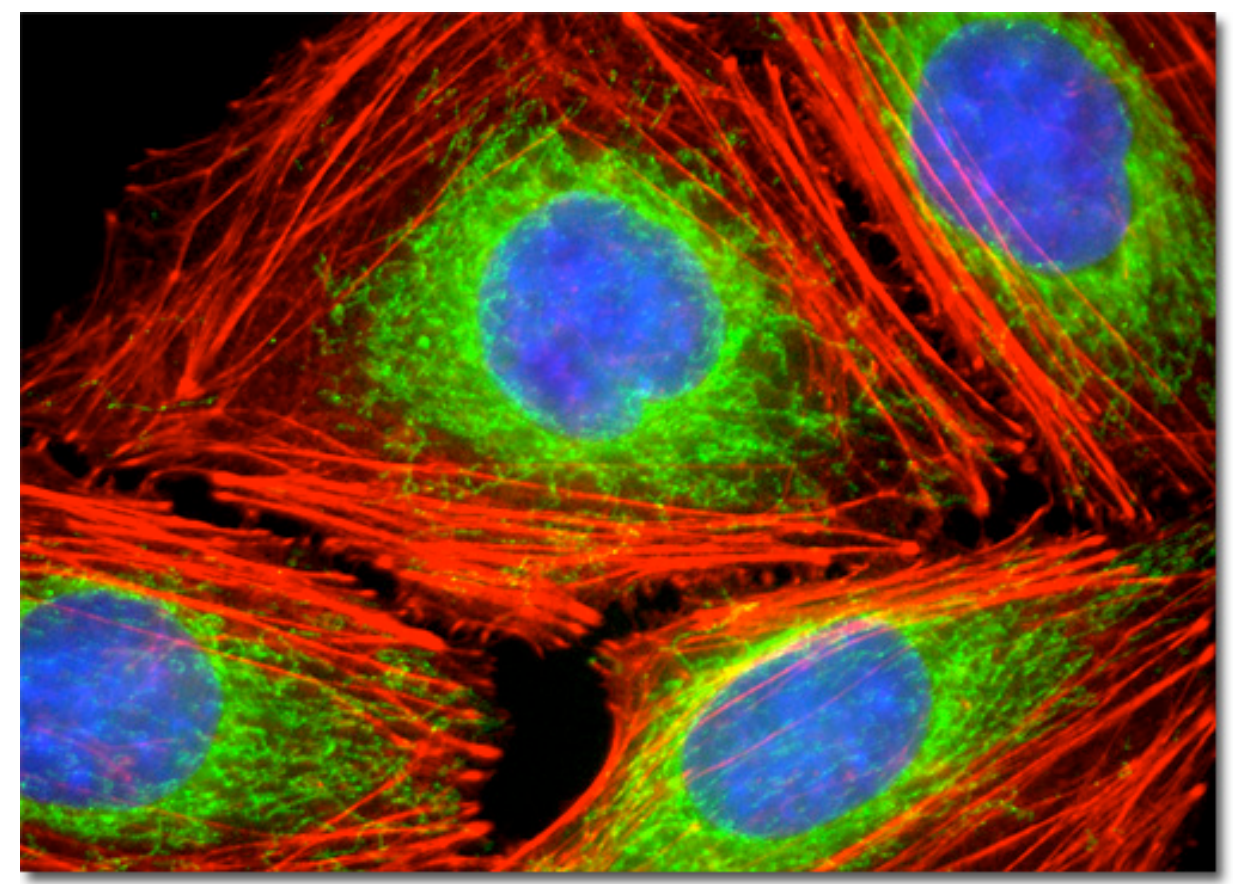

HeLa cells

Olympus Mircoscopy Resource Center

The nucleus is labeled with DAPI (blue)

The Golgi apparatus is labeled with Alexa Fluor 488 (green)

The actin is labeled with Alexa Fluor 568 (red) 


\section{TABLe OF CONTEnTS}

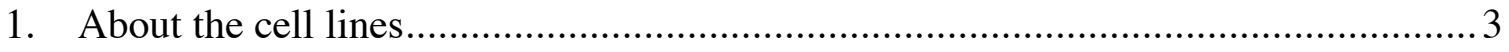

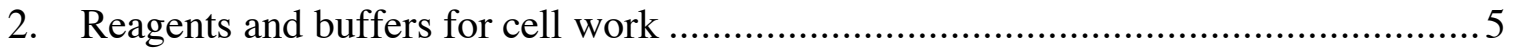

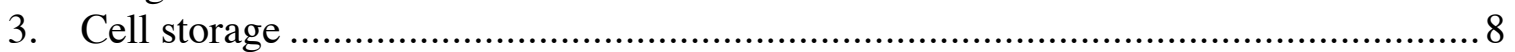

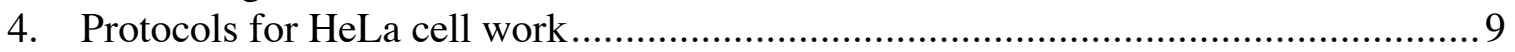

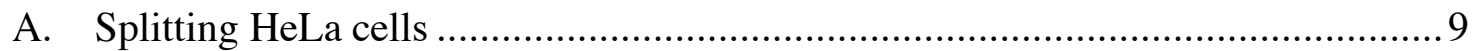

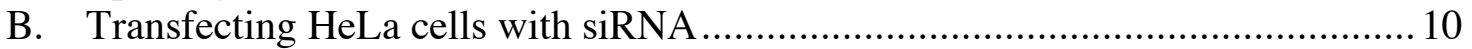

C. Transfecting HeLa cells with plasmid DNA .................................................... 12

D. Example - Finding appropriate RNAi conditions for silencing of the protein GIPC

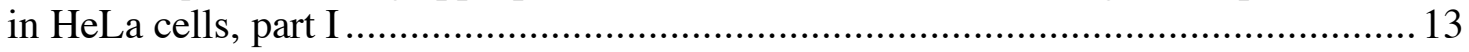

E. Example - Finding appropriate RNAi conditions for silencing of the protein GIPC

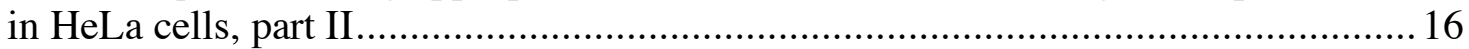

F. Freezing HeLa cells for long-term storage ......................................................2

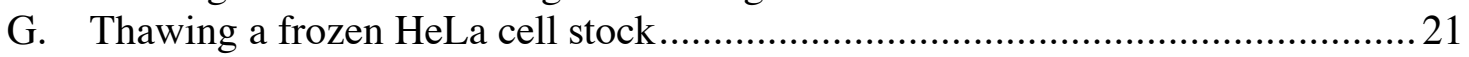

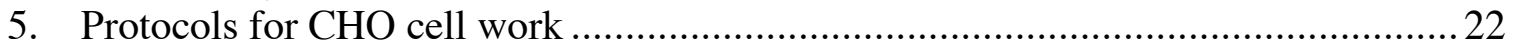

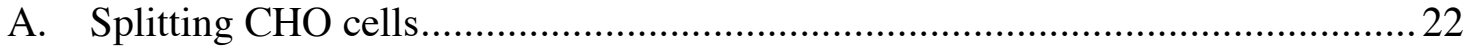

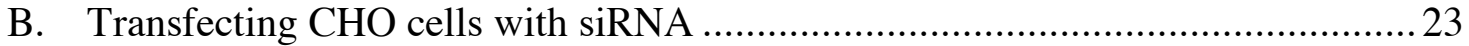

C. Transfecting CHO cells with plasmid DNA...................................................25

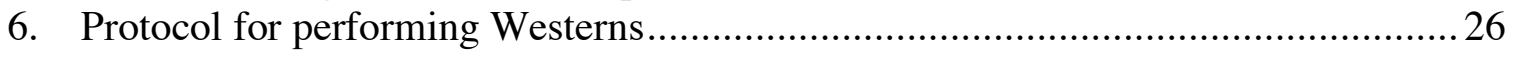

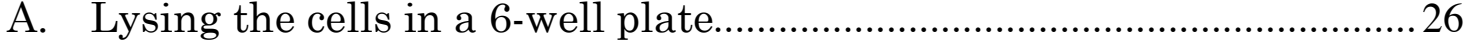

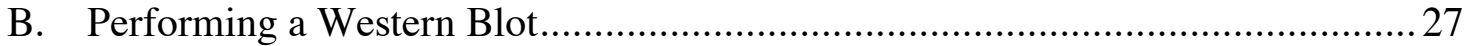

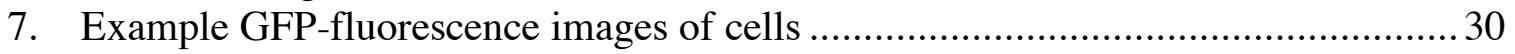

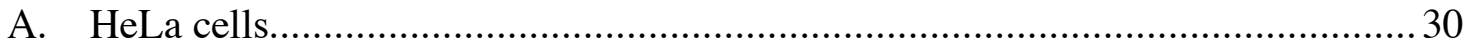

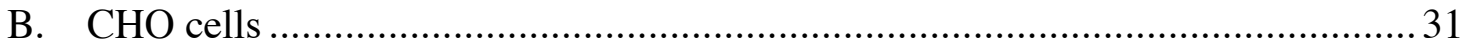

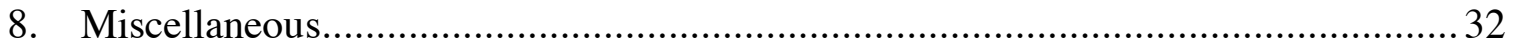




\section{About the Cell Lines}

\section{HeLa cells}

(from Wikipedia, http://en.wikipedia.org/wiki/HeLa)

The cell line was derived from cervical cancer cells taken from Henrietta Lacks, who died from her cancer in 1951. The cells were propagated without Lacks' knowledge or permission by George Otto Gey. Initially, the cell line was said to be named after a "Helen Lane" or "Helen Larson", in order to preserve Lacks' anonymity. These cells are treated as cancer cells, as they are believed to have stemmed from Ms. Lacks' cervical cancer, but a debate still continues on the classification of the cells.

HeLa are considered "immortal": they do not die of old age and can divide an unlimited number of times as long as basic cell survival conditions are met (i.e. being maintained and sustained in a suitable environment). There are many strains of HeLa cells as they continue to evolve by being grown in cell cultures, but all HeLa cells are derived from the same tumour cells removed from Lacks. It has been estimated that the total mass of HeLa cells today far exceeds that of the rest of Henrietta Lacks' body.

\section{CHO cells}

(from Nikon, http://www.microscopyu.com/galleries/confocal/chotwo01.html)

Chinese hamsters are Old World rodents characterized by soft thick fur, large expandable cheek pouches, and relatively long tails. Because this small breed of hamster has a slender body and a tail that is unusually long, it is thought to resemble a mouse and is often referred to as "mouster". Native habitats include open and rather dry areas that extend from Mongolia eastwards to China and Manchuria. In the wild, the burrows of these small creatures can be found along the borders of deserts and in vast semi-dry grass-covered plains.

Chinese hamsters are nocturnal creatures -- they are active at night and sleep during most of the day. Similar to other rodents, these animals rely heavily on the sense of smell and hearing and have relatively poor eyesight. Using their tails for balance, Chinese hamsters are good climbers and are also fast movers. Males are typically larger than females and grow to approximately ten to twelve centimeters in length.

Occasional changes in the genetic makeup of cultured cells allow them to propogate indefinitely, making them effectively immortal. Such lines are said 
to be transformed, and are often used in research as a standardized cell line. Chinese hamster ovary (CHO) cells were introduced in the early 1960s as a viable epithelial cell line containing twin female $\mathrm{X}$ chromosomes. The most common variety of $\mathrm{CHO}$ cells has a nutritional requirement for the amino acid proline, which makes this cell line an ideal candidate for genetic studies. 


\section{REAGENTS AND BUFFERS FOR CELL WORK}

GIBCO/Invitrogen Reagents

\begin{tabular}{|l|l|}
\hline Cat No & \\
\hline $11995-065$ & $500 \mathrm{~mL}$ DMEM (media) \\
\hline $31765-035$ & $500 \mathrm{~mL}$ F-12 (Ham) (media) \\
\hline $31985-070$ & $\begin{array}{l}500 \mathrm{~mL} \text { Opti-MEM I (reduced-serum media for } \\
\text { transfection) }\end{array}$ \\
\hline $25300-054$ & $100 \mathrm{~mL} 0.05 \%$ Trypsin-EDTA (passaging) \\
\hline $10378-016$ & $\begin{array}{l}100 \mathrm{~mL} \text { of 100X stock of Penicillin, Streptomycin, L- } \\
\text { glutamine (antibiotics) }\end{array}$ \\
\hline $26140-079$ & $500 \mathrm{~mL}$ Fetal Bovine Serum for DMEM (Origin: US) \\
\hline
\end{tabular}

HeLa cell growth media: DMEM + 10\% FBS

\begin{tabular}{|l|l|}
\hline DMEM & $500 \mathrm{~mL}$ \\
\hline FBS & $55 \mathrm{~mL}$ \\
\hline Pen/strep antibiotics & $5.5 \mathrm{~mL}$ \\
\hline
\end{tabular}

CHO cell growth media: F-12 + 10\% FBS

\begin{tabular}{|l|l|}
\hline F-12 & $500 \mathrm{~mL}$ \\
\hline FBS & $55 \mathrm{~mL}$ \\
\hline Pen/strep antibiotics & $5.5 \mathrm{~mL}$ \\
\hline
\end{tabular}

CHO serum-free cell growth media: F-12

\begin{tabular}{|l|l|}
\hline F-12 & $500 \mathrm{~mL}$ \\
\hline Pen/strep antibiotics & $5.5 \mathrm{~mL}$ \\
\hline
\end{tabular}


Transfer Buffer - $20 \mathrm{mM}$ Tris base, $150 \mathrm{mM}$ glycine, 20\% methanol

\begin{tabular}{|l|l|}
\hline & 1 Liter transfer buffer \\
\hline Tris base $(\mathrm{g})$ & 3.03 \\
\hline Glycine $(\mathrm{g})$ & 11.26 \\
\hline Methanol $(\mathrm{mL})$ & 200 \\
\hline
\end{tabular}

TBS-T buffer - $20 \mathrm{mM}$ Tris, $\sim 137 \mathrm{mM} \mathrm{NaCl}, 0.1 \%$ Tween-20

\begin{tabular}{|l|l|}
\hline & 1 Liter TBS-T \\
\hline $1 \mathrm{M}$ Tris-HCl, pH 7.6 & $20 \mathrm{~mL}$ \\
\hline $\mathrm{NaCl}$ & $8 \mathrm{~g}$ \\
\hline Tween-20 & $1 \mathrm{~mL}$ \\
\hline
\end{tabular}

Blocking solution - TBS-T $+5 \%$ fat-free dried milk

\begin{tabular}{|l|l|}
\hline & $50 \mathrm{~mL}$ TBS-T \\
\hline TBS-T & $50 \mathrm{~mL}$ \\
\hline Dried milk & $2.5 \mathrm{~g}$ \\
\hline
\end{tabular}

RIPA - 20 mM sodium phosphate (pH 7.5), $0.15 \mathrm{M} \mathrm{NaCl,} \mathrm{1 \%} \mathrm{Triton} \mathrm{X-100,}$ $0.5 \%$ sodium deoxycholate, $0.1 \%$ SDS

\begin{tabular}{|l|l|}
\hline & $250 \mathrm{~mL}$ RIPA \\
\hline $1 \mathrm{M}$ sodium phosphate, $\mathrm{pH} 7.5$ & $5 \mathrm{~mL}$ \\
\hline $5 \mathrm{M} \mathrm{NaCl}$ & $7.5 \mathrm{~mL}$ \\
\hline Triton X-100 & $2.5 \mathrm{~mL}$ \\
\hline $10 \%$ SDS & $2.5 \mathrm{~mL}$ \\
\hline Sodium deoxycholate & 1.25 grams \\
\hline
\end{tabular}

\begin{tabular}{|l|l|}
\hline & $2 \mathrm{M}$ monobasic sodium phosphate \\
\hline Monobasic sodium phosphate & $138 \mathrm{~g}$ \\
\hline Water & $500 \mathrm{~mL}$ \\
\hline
\end{tabular}




\begin{tabular}{|l|l|}
\hline & $2 \mathrm{M}$ dibasic sodium phosphate \\
\hline Dibasic sodium phosphate & $142 \mathrm{~g}$ \\
\hline Water & $500 \mathrm{~mL}$ \\
\hline
\end{tabular}

\begin{tabular}{|l|l|}
\hline & $1 \mathrm{M}$ sodium phosphate, $\mathrm{pH} 7.5$ \\
\hline Monobasic sodium phosphate & $16 \mathrm{~mL}$ \\
\hline Dibasic sodium phosphate & $84 \mathrm{~mL}$ \\
\hline
\end{tabular}




\section{Cell storage}

- Cells are stored in an incubator at $37^{\circ} \mathrm{C}$ and $5 \% \mathrm{CO}_{2}$.

- Cells are maintained in $10 \mathrm{~cm}$ tissue-culture-treated tissue culture dishes (Falcon, Catalog \# 35-3003).

- Surface area: $\sim 79 \mathrm{~cm}^{2}$

- Volume of media: $\sim 10 \mathrm{~mL}$

- Transfections are performed in tissue-culture-treated 6 well plates (Falcon, Catalog \# 35-3046).

- Surface area of a single well: $\sim 9.6 \mathrm{~cm}^{2}$

- Volume of media of single well: $\sim 2 \mathrm{~mL}$ 


\section{Protocols for Hela cell work}

\section{A. Splitting HeLa cells}

The following protocol is for passaging HeLa cells that are $\geq 70 \%$ confluent in a $10 \mathrm{~cm}$ dish.

Before starting the protocol:

- Bring cell media, PBS, and trypsin to room temperature.

- Prepare the new dishes and/or six well plates which will be used for the new split. For example, put the required volumes of cell media into the new dishes.

(1) Aspirate off the cell media.

(2) Wash the cells with $5 \mathrm{~mL}$ PBS.

(3) Aspirate off the PBS.

(4) Add $2 \mathrm{~mL}$ of Trypsin/EDTA. This is just enough to cover the surface of the dish.

(5) Return cells to incubator for $\sim 2$ minutes

(6) Add $8 \mathrm{~mL}$ of cell media to the dish. The FBS quenches the trypsinization.

(7) Pipette media up and down, and squirt it around the surface of the dish to remove adherent cells from the surface.

(8) Move the $10 \mathrm{~mL}$ of cells into a $15 \mathrm{~mL}$ Falcon conical.

(9) Move the appropriate volume of cells into new $10 \mathrm{~cm}$ dishes and/or six well plates.

(10) Spread the cells evenly by rocking the dish/plate back and forth. DO NOT spread the cells by swirling the media in a circular motion - this results in clumping of cells in the middle of the dish.

Typical splits:

- 1:5 dilution of cells in a $10 \mathrm{~cm}$ dish: put $2 \mathrm{~mL}$ of the cells into a dish containing $8 \mathrm{~mL}$ of culture media.

- 1:10 dilution of cells in a $10 \mathrm{~cm}$ dish: put $1 \mathrm{~mL}$ of the cells into a dish containing $9 \mathrm{~mL}$ of culture meda.

- 1:2.7 dilution in a single well of a 6-well plate: put $0.75 \mathrm{~mL}$ of the cells into a well containing $1.25 \mathrm{~mL}$ media. 


\section{B. Transfecting HeLa cells with siRNA}

This following protocol describes RNAi silencing using Ambion siRNA's according to a "reverse transfection" method. This method allows us to transfect cells while performing a split. In other words, transfection of the RNA and passaging of the cells into a 6 -well plate occur concurrently. Thus, the following protocol is used along with the Splitting HeLa cells protocol.

This protocol has been optimized for silencing of the GIPC protein. However, Ambion claims that optimized conditions are consistent for silencing of various proteins for a given cell type.

- Ambion silencer pre-designed siRNA's are stored at $20 \mu \mathrm{M}$ in RNAsefree water.

- Ambion siRNA negative control is stored at $50 \mu \mathrm{M}$.

- Tranfections are performed in a 6-well plate.

Transfection reagent: siPORT NeoFX Lipid-Based Agent for Reverse

Transfection (Ambion, Catalog \#4510)

Before starting the protocol:

- Bring the transfection reagent, OptiMEM, cell media, PBS, Trypsin/EDTA, and RNA to room temperature.

- Spin down the siPORT SiPORT.

(1) Dilute the siPORT in OptiMEM. When putting the siPORT into the OptiMEM, do not directly touch the transfection reagent to the sides of the eppendorf.

\begin{tabular}{|l|l|}
\hline & Single RNAi transfection \\
\hline siPORT $(\mu \mathrm{L})$ & 7 \\
\hline OptiMEM $(\mu \mathrm{L})$ & 93 \\
\hline TOTAL $(\mu \mathrm{L})$ & 100 \\
\hline
\end{tabular}

(2) Dilute the RNA in OptiMEM. We want a final concentration of $\sim 30$ $\mathrm{nM}$ in the transfection reaction.

\begin{tabular}{|l|l|}
\hline & Single RNAi transfection \\
\hline $20 \mu \mathrm{M}$ RNA $(\mu \mathrm{L})$ & 3.75 \\
\hline OptiMEM $(\mu \mathrm{L})$ & 96.25 \\
\hline TOTAL $(\mu \mathrm{L})$ & 100 \\
\hline
\end{tabular}




\begin{tabular}{|l|l|}
\hline & RNAi negative control \\
\hline $50 \mu \mathrm{M}$ RNA $(\mu \mathrm{L})$ & 1.5 \\
\hline OptiMEM $(\mu \mathrm{L})$ & 98.5 \\
\hline TOTAL $(\mu \mathrm{L})$ & 100 \\
\hline
\end{tabular}

(3) Incubate the dilutions for 10 minutes at room temp.

(4) Mix the two dilutions.

(5) Incubate the mixture for 10 minutes at room temp. This allows the RNA and tranfsection reagent to form transfection complexes.

(6) While transfection complexes are being formed, split the cells from a 10 $\mathrm{cm}$ dish (see Splitting HeLa cells protocol). Prepare an appropriate dilution of the cells for the siRNA transfections.

- For each reaction, we want $2 \mathrm{~mL}$ of a 1:2.7 cell dilution (as determined empirically) in a single well of a 6 -well plate.

- This corresponds to $0.75 \mathrm{~mL}$ of cells (from the $10 \mathrm{~mL}$ of trypsinized cells) $+1.25 \mathrm{~mL}$ cell media.

(7) Place $200 \mu \mathrm{L}$ of the transfection complexes in the bottom of each well of a 6 -well plate.

(8) Place $2 \mathrm{~mL}$ of the diluted cells in each well, on top of the complexes.

(9) Mix the cells and transfection complexes by rocking the dish. DO NOT swirl the media in a circular motion - this results in clumping of cells in the middle of the dish.

Optimal silencing occurs 36-48 hours hours after the transfection. 


\section{Transfecting HeLa cells with plasmid DNA}

This following protocol describes transfection of plasmid DNA into cells in a 2 $\mathrm{mL}$ volume in a 6 -well plate. Unlike the protocol for transfecting cells with RNA, this requires that cells have previously been passaged into a 6 -well plate and have adhered to the well surface.

Transfection reagent: Fugene 6 Transfection Reagent (Roche, Catalog \# 11815091001)

\section{Before starting the protocol:}

- Bring the transfection reagent, OptiMEM, and DNA to room temperature.

A single transfection reaction consists of:

\begin{tabular}{|l|l|}
\hline Fugene $(\mu \mathrm{L})$ & 6 \\
\hline DNA $(\mu \mathrm{g})$ & 1 \\
\hline OptiMEM & to $100 \mu \mathrm{L}$ final volume \\
\hline
\end{tabular}

(1) Place the OptiMEM in an eppendorf.

(2) Put the Fugene in the OptiMEM without touching the plastic sides of the tube.

(3) Incubate the mixture for 5 minutes at room temp.

(4) Add the DNA to the Fugene dilution.

(5) Incubate the mixture for 15-45 miutes at room temp.

(6) Aspirate cell media off of the cells in the 6-well plate.

(7) Add $2 \mathrm{~mL}$ of OptiMEM to the cells.

(8) Add $100 \mu \mathrm{L}$ of the transfection complexes to the well drop-wise.

(9) Spread the transfection complexes evenly over the cells by rocking the plate.

(10) 4 hours after the transfection, replace the media with normal cell media (DMEM + FBS).

Image cells $\sim 12$ hours after transfection. 


\section{Example - Finding appropriate RNAi conditions for silencing of the protein GIPC in HeLa cells, part I}

This protocol is based on the Transfecting HeLa cells with siRNA protocol. The goal is to look at a variety of silencing reactions performed at constant siRNA concentration and varying amounts of transfection reagent to optimize silencing.

5 silencing reactions were performed:

(1) GIPC siRNA + volume \#1 (3 $\mu \mathrm{L})$ of transfection reagent

(2) GIPC siRNA + volume \#2 (5 $\mu \mathrm{L})$ of transfection reagent

(3) GIPC siRNA + volume \#3 $(9 \mu \mathrm{L})$ of transfection reagent

(4) Negative control siRNA transfection in $5 \mu \mathrm{L}$ of transfection reagent

(5) Buffer control transfection in $5 \mu \mathrm{L}$ of transfection reagent

Transfection reagent: siPORT NeoFX Lipid-Based Agent for Reverse Transfection (Ambion, Catalog \#4510)

siRNA: GIPC siRNA ID\# 256502

(1) Dilute the siPORT in OptiMEM. When putting the siPORT into the OptiMEM, do not directly touch the transfection reagent to the sides of the eppendorf.

\begin{tabular}{|l|l|l|l|}
\hline & $\begin{array}{l}\text { Volume \#1 } \\
3 \mu \mathrm{L} \text { volume }\end{array}$ & $\begin{array}{l}\text { Volume \#2 } \\
5 \mu \mathrm{L} \text { volume }\end{array}$ & $\begin{array}{l}\text { Volume \#3 } \\
9 \mu \mathrm{L} \text { volume }\end{array}$ \\
\hline siPORT $(\mu \mathrm{L})$ & 3 & 15 & 9 \\
\hline OptiMEM $(\mu \mathrm{L})$ & 97 & 285 & 91 \\
\hline TOTAL $(\mu \mathrm{L})$ & 100 & 300 & 100 \\
\hline
\end{tabular}

NOTE - there is enough diluted siPORT at Volume \#2 to do three transfections. This is so we can do the negative and buffer-only controls.

(2) Dilute the RNA in OptiMEM. We want a final concentration of $\sim 30$ $\mathrm{nM}$ in the transfection reaction.

\begin{tabular}{|l|l|}
\hline & Single RNAi transfection \\
\hline $20 \mu \mathrm{M}$ RNA $(\mu \mathrm{L})$ & 15 \\
\hline OptiMEM $(\mu \mathrm{L})$ & 385 \\
\hline TOTAL $(\mu \mathrm{L})$ & 400 \\
\hline
\end{tabular}


NOTE - this is enough to do 4 reactions. This allows us to have enough for our three transfections without worrying about accidentally running short.

\begin{tabular}{|l|l|l|}
\hline & RNAi negative control & Buffer-only control \\
\hline $50 \mu \mathrm{M}$ RNA $(\mu \mathrm{L})$ & 1.5 & 0 \\
\hline OptiMEM $(\mu \mathrm{L})$ & 98.5 & 100 \\
\hline TOTAL $(\mu \mathrm{L})$ & 100 & 100 \\
\hline
\end{tabular}

(3) Incubate the dilutions for 10 minutes at room temp.

(4) Mix the two dilutions.

\begin{tabular}{|c|c|c|c|c|c|}
\hline & $\# 1$ & $\# 2$ & $\# 3$ & $\# 4$ & \#5 \\
\hline $\begin{array}{l}\text { NeoFX } \\
\text { dilution }(\mu \mathrm{L})\end{array}$ & $\begin{array}{l}100 \\
\text { Volume \#1 }\end{array}$ & $\begin{array}{l}100 \\
\text { Volume \#2 }\end{array}$ & $\begin{array}{l}100 \\
\text { Volume \#3 }\end{array}$ & $\begin{array}{l}100 \\
\text { Volume \#2 }\end{array}$ & $\begin{array}{l}100 \text { Volume } \\
\# 2\end{array}$ \\
\hline $\begin{array}{l}\text { RNA } \\
\text { dilution }(\mu \mathrm{L})\end{array}$ & $\begin{array}{l}100 \text { GIPC } \\
\text { siRNA }\end{array}$ & $\begin{array}{l}100 \text { GIPC } \\
\text { siRNA }\end{array}$ & $\begin{array}{l}100 \text { GIPC } \\
\text { siRNA }\end{array}$ & $\begin{array}{l}100 \text { buffer } \\
\text { control }\end{array}$ & $\begin{array}{l}100 \text { negative } \\
\text { control }\end{array}$ \\
\hline TOTAL $(\mu \mathrm{L})$ & 200 & 200 & 200 & 200 & 200 \\
\hline
\end{tabular}

(5) Incubate the mixture for 10 minutes at room temp. This allows the RNA and tranfsection reagent to form transfection complexes.

(6) While transfection complexes are being formed, split the cells from a $10 \mathrm{~cm}$ dish (see Splitting HeLa cells protocol). Prepare an appropriate dilution of the cells for the siRNA transfections.

- Combine $4.5 \mathrm{~mL}$ of cells (from the $10 \mathrm{~mL}$ of trypsinized cells) +7.5 $\mathrm{mL}$ of cell media. This is enough for 6 silencing reactions (though we only need enough for 5 .

(7) Place $200 \mu \mathrm{L}$ of the transfection complexes in the bottom of 5 wells of a 6 -well plate.

(8) Place $2 \mathrm{~mL}$ of the diluted cells in each well, on top of the complexes.

(9) Mix the cells and transfection complexes by rocking the dish. DO NOT swirl the media in a circular motion - this results in clumping of cells in the middle of the dish.

Following the transfection:

- Check every 12 hours by eye to see if cell viability has been compromised in any of the RNAi conditions.

- After 24-36 hours, lyse the cells in each well and perform a Western analysis of the five conditions to compare the extent of GIPC silencing (see the Lysing the cells in a 6-well plate and Performing a Western Blot protocols). The amount of cell lysate to use for a Western must be determined empirically for a 
particular antibody - for our GIPC antibody, $5 \mu \mathrm{L}$ of lysate is sufficient. 


\section{E. Example - Finding appropriate RNAi conditions for silencing of the protein GIPC in HeLa cells, part II}

From the previous example protocol, we determined the optimal concentration of transfection reagent for silencing of the GIPC protein. The next goal is to determine the optimal duration of silencing.

To determine this, we again use the Transfecting HeLa cells with siRNA protocol. This time, however, we perform numerous silencing reactions, all at the same siRNA concentration and siPORT volume, but we allow the duration of silencing to vary.

Each RNA transfection must be conducted in a different 6-well plate. This is because we are going to lyse cells at a variety of time points, and we don't want to affect other wells in a plate. Every 12-24 hours, lyse the cells in a well and store the lysate. Perform a Western analysis of the various time points to compare the extent of GIPC silencing.

Shown below is a Western blot analysis of cells that have been silenced for GIPC expression using 2 different siRNA's (siRNA \#1 and siRNA \#2) against GIPC. Each silencing reaction occurs over 12, 24, 36, or 48 hours, and each blot consists of $5 \mu \mathrm{L}$ of cell lysate (see the Lysing the cells in a 6-well plate protocol). It is apparent that GIPC siRNA \#2 does not silence GIPC expression.

HeLa cells transfected with negative control siRNA were incubated for 48 hours, and different volumes of the lysate from these negative control cells were included in the Western blot. These negative control blots allow us to determine the extent of GIPC silencing (see the analysis below). The blot also includes $5 \mu \mathrm{L}$ of lystae from HeLa cells transfected with buffer as a control. 


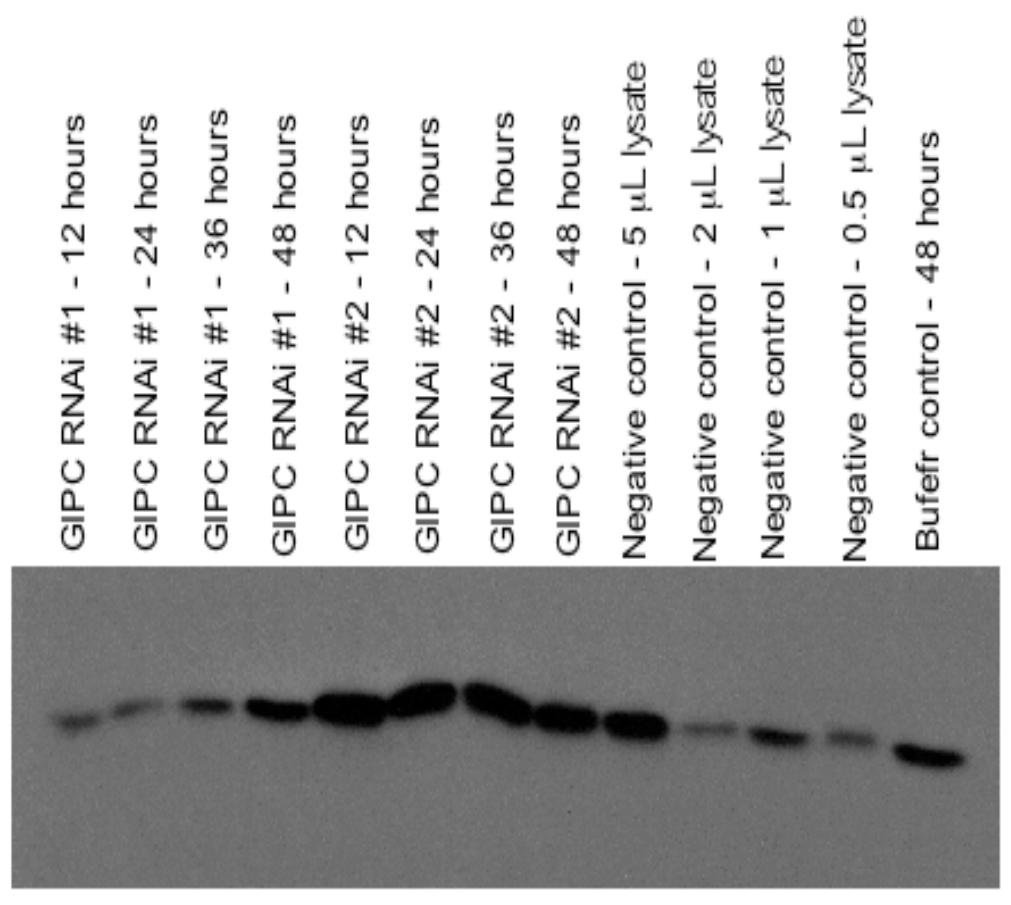

The following describes analysis of the above Western Blot to determine the extent of silencing after 48 hours of silencing with siRNA \#1:

I used a scanner to create a high resolution TIF-image of the Western blot. Using ImageJ Software (NIH, http://rsb.info.nih.gov/ij/) I created line scans through the center of each lane of the Western blot. From each scan, I subtracted a background value corresponding to the mean value of a linescan collected in a blank area of the blot. 

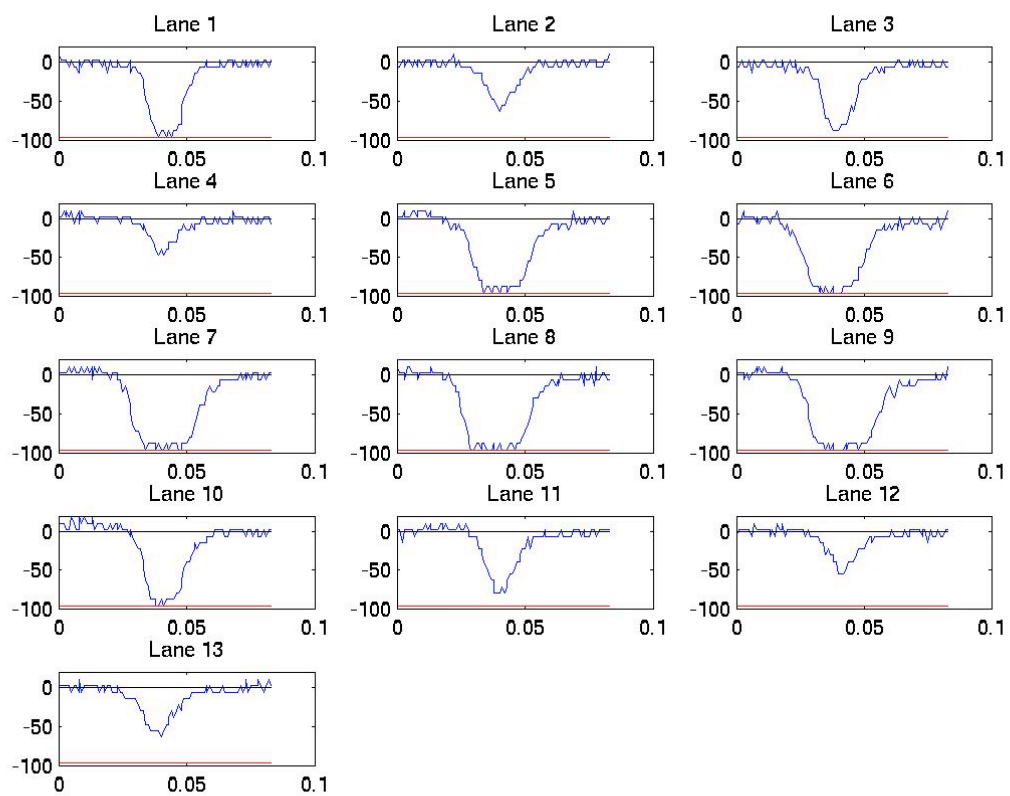

Red lines correspond to the minimum value in lane 5 , which is obviously saturated. From these lines, we see that lanes 1, 6, 7, 8, 9, and probably 10 are also saturated.

The total protein concentration of all cell lysates was determined using the Pierce BCA (bicinchoninic acid) kit. The following are the concentrations of the unsaturated lanes in which we are interested:

\begin{tabular}{|l|l|l|}
\hline Lane 2 & $0.49 \mathrm{mg} / \mathrm{mL}$ & $5 \mu \mathrm{L}$ GIPC RNAi \#1 -24 hours \\
\hline Lane 3 & $0.35 \mathrm{mg} / \mathrm{mL}$ & $5 \mu \mathrm{L}$ GIPC RNAi \#1 -36 hours \\
\hline Lane 4 & $0.28 \mathrm{mg} / \mathrm{mL}$ & $5 \mu \mathrm{L}$ GIPC RNAi \#1 -48 hours \\
\hline Lane 11 & $0.37 \mathrm{mg} / \mathrm{mL}$ & $1 \mu \mathrm{L}$ Negative control -48 hours \\
\hline Lane 12 & $0.38 \mathrm{mg} / \mathrm{mL}$ & $0.5 \mu \mathrm{L}$ Negative control -48 hours \\
\hline
\end{tabular}

In Image J, I calculated the integrated intensity in a box of fixed size centered over each lane. The integrated intensity for this same box was also determined in a blank region of the blot:

\begin{tabular}{|l|l|}
\hline Lane 2 & 0.421 \\
\hline Lane 3 & 0.392 \\
\hline Lane 4 & 0.428 \\
\hline Lane 11 & 0.421 \\
\hline Lane 12 & 0.435 \\
\hline Background & 0.462 \\
\hline
\end{tabular}


The total intensity of a lane is described by the intensity of the lane subtracted from the intensity of the background. I used Lanes 11 and 12 to determine a conversion between total protein mass and total intensity on the Western blot for un-silenced cells. The fit line is forced to pass through zero:

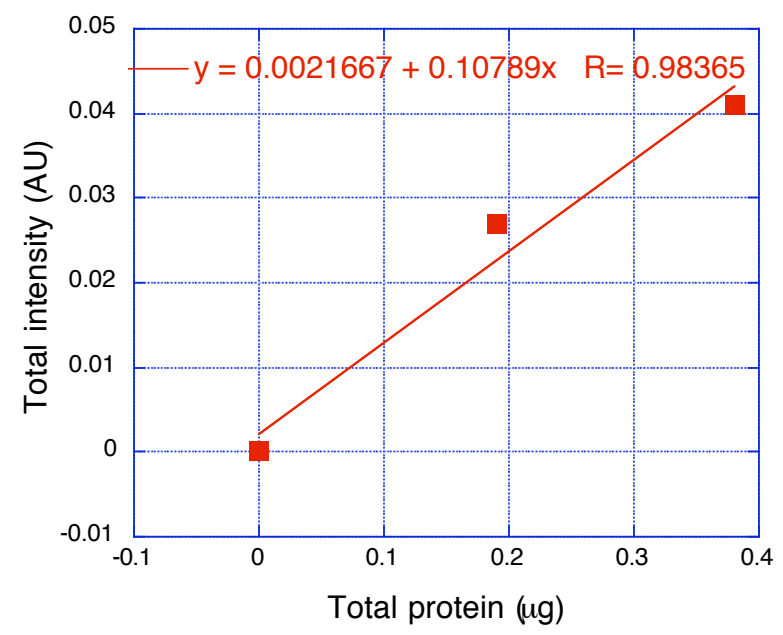

For cells that have been silenced for 48 hours with siRNA \#1 (Lane 4), we compare the observed total intensity on the blot to the expected total intensity for un-silenced cells (as determined from the fit line above). The ratio of these two values gives us the fraction of GIPC remaining.

\begin{tabular}{|l|l|l|l|l|}
\hline & $\begin{array}{l}\text { Total protein } \\
\text { (ug) }\end{array}$ & $\begin{array}{l}\text { Expected total } \\
\text { intensity }\end{array}$ & $\begin{array}{l}\text { Actual total } \\
\text { intensity }\end{array}$ & $\begin{array}{l}\text { Actual / } \\
\text { Expected }\end{array}$ \\
\hline Lane 4 & 1.40 & 0.153 & 0.034 & 0.22 \\
\hline
\end{tabular}

So, about $80 \%$ silencing of GIPC occurs after 48 hours. 


\section{F. Freezing HeLa cells for long-term storage}

This protocol is for preparation of frozen cell stocks from confluent cells on the surface of a $10 \mathrm{~cm}$ dish. Cells must be stored in special tubes which can be stored in liquid nitrogen (cryo-tubes).

- One vial of frozen HeLa cells (from an "early" passage) is good for $\sim 50$ passages.

Before starting the protocol:

- Prepare and sterile filter freezing media - $10 \%$ DMSO, 20\% FBS in DMEM cell media ( 1 mL / cryo-tube)

\begin{tabular}{|l|l|}
\hline & $10 \mathrm{~mL}$ freezing media \\
\hline DMSO $(\mathrm{mL})$ & 1 \\
\hline FBS $(\mathrm{mL})$ & 2 \\
\hline DMEM $(\mathrm{mL})$ & 7 \\
\hline
\end{tabular}

- Bring cell media, PBS, and trypsin to room temperature.

(1) Aspirate off the cell media.

(2) Wash the cells with $5 \mathrm{~mL}$ PBS.

(3) Aspirate off the PBS.

(4) Add $2 \mathrm{~mL}$ of Trypsin/EDTA. This is just enough to cover the surface of the dish.

(5) Return cells to incubator for $\sim 2$ minutes

(6) Add $8 \mathrm{~mL}$ of cell media to the dish. The FBS quenches the trypsinization.

(7) Pipette media up and down, and squirt it around the surface of the dish to remove adherent cells from the surface.

(8) Move the $10 \mathrm{~mL}$ of cells into a $15 \mathrm{~mL}$ Falcon conical.

(9) Spin down the cells in a clinical centrifuge (2-3 minutes at 500 rpm).

(10) Carefully pull off the supernatant.

(11) Re-suspend cells in $1 \mathrm{~mL}$ of freezing media; transfer to a cryo-tube.

- Ideally, you want $\sim 1$ million cells/cryo-tube. When thawed, this amount of cells results in sufficient density for healthy cell growth, while allowing cells to grow for about 1 day before passaging.

- One million cells is $\sim 60 \%$ confluency in a $10 \mathrm{~mL}$ dish.

(12) To freeze cells slowly, place the cryotube in a Styrofoam container at $-80^{\circ} \mathrm{C}$ overnight. Then transfer to liquid nitrogen storage the next day.

- The Styrofoam container can be fairly crude - for example, you can embed the cryotube in the Styrofoam-holder from a pack of $50 \mathrm{~mL}$ Falcon tubes.

- Nalgene also sells more sophisticated cooling systems (i.e. "Mr. Frosty") 


\section{G. Thawing a frozen HeLa cell stock}

This protocol is for thawing a frozen stock of HeLa cells (as described in the Freezing HeLa cells for long-term storage protocol) and transferring the thawed cells to a $10 \mathrm{~cm}$ dish. Go through this protocol as quickly as possible.

Before starting the protocol:

- Pre-warm $20 \mathrm{~mL}$ of cell media to $37^{\circ} \mathrm{C}$, and place $10 \mathrm{~mL}$ each in two $15 \mathrm{~mL}$ Falcon tubes.

(1) Quickly thaw the cells in a $37^{\circ} \mathrm{C}$ bath. Make sure the lid is tight and the cryo-tube remains upright in the bath to avoid contamination. You may want to carefully wipe the sides of the tube with $70 \%$ ethanol to avoid contamination.

(2) Transfer the $1 \mathrm{~mL}$ of cells into $10 \mathrm{~mL}$ of pre-warmed media. This dilutes out the DMSO.

(3) Spin the cells down in a clinical centrifuge (2-3 minutes at 500 rpm).

(4) Pull off the supernatant, and re-suspend the cells in $10 \mathrm{~mL}$ of prewarmed cell media.

(5) Plate onto a $10 \mathrm{~cm}$ dish. 


\section{Protocols For CHO CELl WORK}

\section{A. Splitting CHO cells}

The following protocol is for passaging $\mathrm{CHO}$ cells that are $\geq 70 \%$ confluent in a $10 \mathrm{~cm}$ dish. This protocol is identical to the protocol for HeLa cells, though $\mathrm{CHO}$ cells appear to proliferate faster.

\section{Before starting the protocol:}

- Bring cell media, PBS, and trypsin to room temperature.

- Prepare the new dishes and/or six well plates which will be used for the new split. For example, put the required volumes of cell media into the new dishes.

(6) Aspirate off the cell media.

(7) Wash the cells with $5 \mathrm{~mL}$ PBS.

(8) Aspirate off the PBS.

(9) Add $2 \mathrm{~mL}$ of Trypsin/EDTA. This is just enough to cover the surface of the dish.

(10) Return cells to incubator for $\sim 2$ minutes

(11) Add $8 \mathrm{~mL}$ of cell media to the dish. The FBS quenches the trypsinization.

(12) Pipette media up and down, and squirt it around the surface of the dish to remove adherent cells from the surface.

(13) Move the $10 \mathrm{~mL}$ of cells into a $15 \mathrm{~mL}$ Falcon conical.

(14) Move the appropriate volume of cells into new $10 \mathrm{~cm}$ dishes and/or six well plates.

(15) Spread the cells evenly by rocking the dish/plate back and forth. DO NOT spread the cells by swirling the media in a circular motion - this results in clumping of cells in the middle of the dish.

Typical splits:

- 1:5 dilution of cells in a $10 \mathrm{~cm}$ dish: put $2 \mathrm{~mL}$ of the cells into a dish containing $8 \mathrm{~mL}$ of culture media.

- 1:10 dilution of cells in a $10 \mathrm{~cm}$ dish: put $1 \mathrm{~mL}$ of the cells into a dish containing $9 \mathrm{~mL}$ of culture meda.

- 1:2.7 dilution in a single well of a 6 -well plate: put $0.75 \mathrm{~mL}$ of the cells into a well containing $1.25 \mathrm{~mL}$ media. 


\section{B. Transfecting CHO cells with siRNA}

This following protocol describes RNAi silencing using Ambion siRNA's according to a "reverse transfection" method. This protocol is nearly identical to the HeLa protocol, though it has not yet been optimized. Unknown quantities that must be determined are marked by a question mark.

- Ambion silencer pre-designed siRNA's are stored at $20 \mu \mathrm{M}$ in RNAsefree water.

- Ambion siRNA negative control is stored at $50 \mu \mathrm{M}$.

- Tranfections are performed in a 6-well plate.

Transfection reagent: siPORT Amine Lipid-Based Agent for Reverse Transfection (Ambion, Catalog \#4502)

Before starting the protocol:

- Bring the transfection reagent, OptiMEM, cell media, PBS, Trypsin/EDTA, and RNA to room temperature.

- Spin down the siPORT SiPORT.

(1) Dilute the siPORT in OptiMEM. When putting the siPORT into the media, do not directly touch the transfection reagent to the sides of the eppendorf.

\begin{tabular}{|l|l|}
\hline & Single RNAi transfection \\
\hline siPORT $(\mu \mathrm{L})$ & $\boldsymbol{?}$ \\
\hline OptiMEM $(\mu \mathrm{L})$ & $\boldsymbol{?}$ \\
\hline TOTAL $(\mu \mathrm{L})$ & 100 \\
\hline
\end{tabular}

(2) Dilute the RNA in OptiMEM. We want a final concentration of $\sim 30$ $\mathrm{nM}$ in the transfection reaction.

\begin{tabular}{|l|l|}
\hline & Single RNAi transfection \\
\hline $20 \mu \mathrm{M}$ RNA $(\mu \mathrm{L})$ & 3.75 \\
\hline OptiMEM $(\mu \mathrm{L})$ & 96.25 \\
\hline TOTAL $(\mu \mathrm{L})$ & 100 \\
\hline
\end{tabular}

\begin{tabular}{|l|l|}
\hline & RNAi negative control \\
\hline $50 \mu \mathrm{M}$ RNA $(\mu \mathrm{L})$ & 1.5 \\
\hline OptiMEM $(\mu \mathrm{L})$ & 98.5 \\
\hline TOTAL $(\mu \mathrm{L})$ & 100 \\
\hline
\end{tabular}


(3) Incubate the dilutions for 10 minutes at room temp.

(4) Mix the two dilutions.

(5) Incubate the mixture for 10 minutes at room temp. This allows the RNA and tranfsection reagent to form transfection complexes.

(6) While transfection complexes are being formed, split the cells from a $10 \mathrm{~cm}$ dish (see Splitting CHO cells protocol). Prepare an appropriate dilution of the cells for the siRNA transfections.

- For each reaction, we want $2 \mathrm{~mL}$ of a 1:2.7 cell dilution (as determined empirically) in a single well of a 6 -well plate.

- This corresponds to $0.75 \mathrm{~mL}$ of cells (from the $10 \mathrm{~mL}$ of trypsinized cells) $+1.25 \mathrm{~mL}$ cell media.

(7) Place $200 \mu \mathrm{L}$ of the transfection complexes in the bottom of each well of a 6 -well plate.

(8) Place $2 \mathrm{~mL}$ of the diluted cells in each well, on top of the complexes.

(9) Mix the cells and transfection complexes by rocking the dish. DO NOT swirl the media in a circular motion - this results in clumping of cells in the middle of the dish.

Optimal silencing occurs ??? hours after the transfection. 


\section{Transfecting CHO cells with plasmid DNA}

This following protocol describes transfection of plasmid DNA into cells in a 2 $\mathrm{mL}$ volume in a 6 -well plate. Unlike the protocol for transfecting cells with RNA, this requires that cells have previously been passaged into a 6 -well plate and have adhered to the well surface.

Transfection reagent: Fugene 6 Transfection Reagent (Roche, Catalog \# 11815091001)

\section{Before starting the protocol:}

- Bring the transfection reagent, serum-free media, and DNA to room temperature.

A single transfection reaction consists of:

\begin{tabular}{|l|l|}
\hline Fugene $(\mu \mathrm{L})$ & 3 \\
\hline DNA $(\mu \mathrm{g})$ & 1 \\
\hline $\begin{array}{l}\text { Serum-free } \\
\text { culture media }\end{array}$ & to $100 \mu \mathrm{L}$ final volume \\
\hline
\end{tabular}

(1) Place the serum-free media in an eppendorf.

(2) Put the Fugene in the media without touching the plastic sides of the tube.

(3) Incubate the mixture for 5 minutes at room temp.

(4) Add the DNA to the Fugene dilution.

(5) Incubate the mixture for 15-45 miutes at room temp.

(6) Aspirate cell media off of the cells in the 6-well plate.

(7) Add $2 \mathrm{~mL}$ of serum-free media to the cells.

(8) Add $100 \mu \mathrm{L}$ of the transfection complexes to the well drop-wise.

(9) Spread the transfection complexes evenly over the cells by rocking the plate.

(10) 4 hours after the transfection, replace the media with normal cell media (F-12 + FBS).

Image cells $\sim 10-12$ hours after transfection. 


\section{Protocol for Performing Westerns}

\section{A. Lysing the cells in a 6-well plate}

Before starting the protocol:

- Make RIPA + $1 \mathrm{mM}$ PMSF + protease inhibitor cocktail + $1 \mathrm{mM}$ EDTA

\begin{tabular}{|l|l|}
\hline & $500 \mu \mathrm{L}$ \\
\hline RIPA $(\mu \mathrm{L})$ & 477 \\
\hline Roche protease cocktail $(25 \mathrm{x})(\mu \mathrm{L})$ & 20 \\
\hline 0.5 M EDTA $(\mu \mathrm{L})$ & 1 \\
\hline 0.25 M PMSF $(\mu \mathrm{L})$ & 2 \\
\hline
\end{tabular}

(1) Put the 6-well plate on ice so that the bottom of the well is making complete contact with ice.

- Placing a KimWipe between the plate and the ice helps make complete contact.

(2) Aspirate off the media in the well.

(3) Wash the cells 5-times with PBS.

- It is important to wash away all the FBS.

(4) Add $200 \mu \mathrm{L}$ of the RIPA + PMSF + protease inhibitor mixture.

(5) Leave on ice for 20 minutes.

(6) Scrape the bottom of the well with a rubber-policeman to remove all cells from the surface.

(7) Pull off the $200 \mu \mathrm{L}$ of lysed cells.

(8) Spin for 15 minutes at $55 \mathrm{k}$ and $4^{\circ} \mathrm{C}$ in a TLA 100 rotor.

(9) Pull of the supernatant.

To determine how much of the cell lysate is necessary for Western blot analysis for a protein of interest, run a Western blot for your protein using a variety of volumes of the cell lysate (i.e. blot for your protein in $5 \mu \mathrm{L}, 10 \mu \mathrm{L}$, and $20 \mu \mathrm{L}$ of lysate).

- For GIPC in HeLa cells - only $5 \mu \mathrm{L}$ of cell lysate is required for detection of GIPC protein by our anti-GIPC antibody.

Use a BCA kit (bicinchoninic acid assay) to determine the total protein concentration of the cell lysate. This will allow you to use consistent amounts of total cell lysate protein from experiment-to-experiment 


\section{B. Performing a Western Blot}

Before starting the protocol:

- Prepare 1-2 L of TBS-T Buffer.

- From the TBS-T buffer, prepare $50 \mathrm{~mL}$ blocking solution. This requires $\sim 10$

- minutes of mixing to dissolve completely.

- Prepare $\sim 1 \mathrm{~L}$ of transfer buffer.

(1) Run out identical protein samples on two SDS-PAGE gels. One gel will be stained with Coomassie while the other will be used for the Western blot.

(2) Transfer the protein to a nitrocellulose membrane:

a. Soak the transfer cassette and sponges in a container filled with transfer buffer.

b. Cut two pieces of Whatman filter paper to the size of the sponge. - Use a dry sponge as a template.

c. Place one of the wet sponges on the black-side of the transfer cassette.

d. Soak the two sponge-sized pieces of Whatman paper in transfer buffer and put them on top of the wet sponge on the cassette.

e. Carefully open up the SDS-PAGE gel plates, leaving the gel attached to one of the plates.

f. Use a clean razor blade to cut off the gel wells and put a notch in one corner of the gel. This notch will define the orientation of the gel for the rest of the protocol.

g. Put the gel on top of the Whatman filter papers on the cassette.

h. Wearing clean, dry gloves, carefully cut a piece of nitrocellulose paper to the size of the gel; cut a notch in the corner of the nitrocellulose paper for purposes of orientation.

i. Soak the nitrocellulose in the transfer buffer, until it is thoroughly and evenly wet.

j. Carefully put the nitrocellulose membrane on top of the gel, lining up the notches.

Once the nitrocellulose membrane touches the gel, the transfer process starts. Don't slide the nitrocellulose around on the gel once they're in contact.

- "Bumps" will often show up at the edge of the gel (especially if it dries out a bit). Try wetting these with buffer and pushing them away with your fingers.

$k$. Cut two more pieces of Whatman filter paper to the size of the nitrocellulose. Soak them in transfer buffer and put them on top of the nitrocellulose.

1. Soak the second sponge in Transfer Buffer and put it on top of the Whatman filter paper.

m. Close and lock the cassette. 
- The cassette contains the following sandwich: sponge, 2 pieces of Whatman paper, SDS-PAGE gel, nitrocellulose, 2 pieces of Whatman paper, sponge.

n. Put the cassette into the transfer box, so that the black side of the transfer cassette faces the black side of the box.

o. Fill the transfer box with transfer buffer. An ice block can be included in the transfer box to keep the temperature down during the transfer. Alternatively, the transfer box can be moved to a cold room.

p. Transfer the protein at $300 \mathrm{~mA}$ for 1 hour or $150 \mathrm{~mA}$ for 2 hours or 40 $\mathrm{mA}$ for 16 hours/overnight (do the latter at $4^{\circ} \mathrm{C}$ ).

q. Remove the cassette from the transfer box and open it.

r. Use tweezers to remove everything on top of the nitrocellulose paper.

s. Put the nitrocellulose in a small container (i.e. the bottom of a $2 \mu \mathrm{L}$ pipette-tip box) and start the washing/antibody binding steps as detailed below.

- Put the nitrocellulose in the box with the transferred side facing up.

t. Coomassie stain the gel to determine the extent of transfer.

(3) Immerse the membrane in blocking solution and place on a shaker at room temperature for 1 hour. This blocks non-specific binding sites. You may also leave the membrane in the Blocking Solution overnight at $4^{\circ} \mathrm{C}$.

(4) Wash the membrane 3 times with TBS-T. For each wash, leave the membrane on a shaker for 10 minutes at room temp.

(5) Dilute the primary antibody into TBS-T. The dilution factor is determined empirically. Use a minimal volume of TBS-T, enough to cover the membrane but no more.

- For a $2 \mu \mathrm{L}$ pipette box, $20 \mathrm{~mL}$ should be sufficient.

- First place the TBS-T onto the membrane, and then add the antibody directly to the container.

- For anti-GIPC rabbit polyclonal antibody, a 1:6000 dilution is appropriate.

- For anti-Dab2 mouse polyclonal antibody, a 1:1000 dilution is appropriate.

(6) Incubate the membrane in the diluted primary antibody for 1 hour, room temperature on a shaker.

(7) Wash the membrane 3 times with TBS-T. For each wash, leave the membrane on a shaker for 10 minutes at room temp.

(8) Dilute the secondary antibody into TBS-T. Follow the manufacturer's recommendation for a dilution factor. Use a minimal TBS-T volume, enough to cover the membrane but no more.

- For the BioRad Blotting grade affinity purified Goat Anti-Rabbit IgG $(\mathrm{H}+\mathrm{L})$ Horse Radish Peroxidase Conjugate, use a 1:3000 dilution. 
(9) Incubate the membrane in the diluted secondary antibody for 1 hour, room temperature on a shaker.

(10) Wash the membrane 3 times with TBS-T. For each wash, leave the membrane on a shaker for 10 minutes at room temp.

(11) Dry the membrane by placing it between two pieces of Whatman filter paper. This is to remove excess liquid - but the nitrocellulose should not be made bone-dry.

(12) For an HRP-conjugated secondary antibody, use the Amersham ECL detection reagent:

a. In a small tray, combine equal volumes of ECL 1 and ECL 2; swirl the tray to mix the reagents. Use minimal volumes, just enough so that the final volume will just cover the membrane.

- Put $1 \mathrm{~mL}$ of ECL 1 in the center of the tray, put $1 \mathrm{~mL}$ of ECL 2 directly on top of it, and mix.

b. Place the membrane in the tray and swirl the contents of the tray over the membrane.

c. Dry the membrane between two pieces of Whatman filter paper.

d. Wrap the membrane in plastic wrap or put it between two pieces of transparency.

If using an AP-conjugated secondary, then use the Amersham CDP-Star detection reagent. Follow the same steps as in 15, above, except that there is only the one detection reagent.

(13) Take your wrapped membrane, a film cassette, some tape, a pair of scissors and a box of film to the dark room.

(14) Open the film cassette and tape your membrane to one side of the film cassette. Place a piece of film on top of your membrane.

(15) Close the cassette to expose the film.

a. For the HRP-conjugate/ECL detection, exposure can be anywhere from 30 seconds to several minutes. Once you develop the film you'll know if you need to take a longer or shorter second exposure.

b. For the AP-conjugate/CDP-Star detection, expose the film for one hour.

(16) Develop the film. 


\section{EXAMPLE GFP-FLUORESCENCE IMAGES OF CELLS}

\section{A. HeLa cells}

Expression of GFP-myosin VI full length

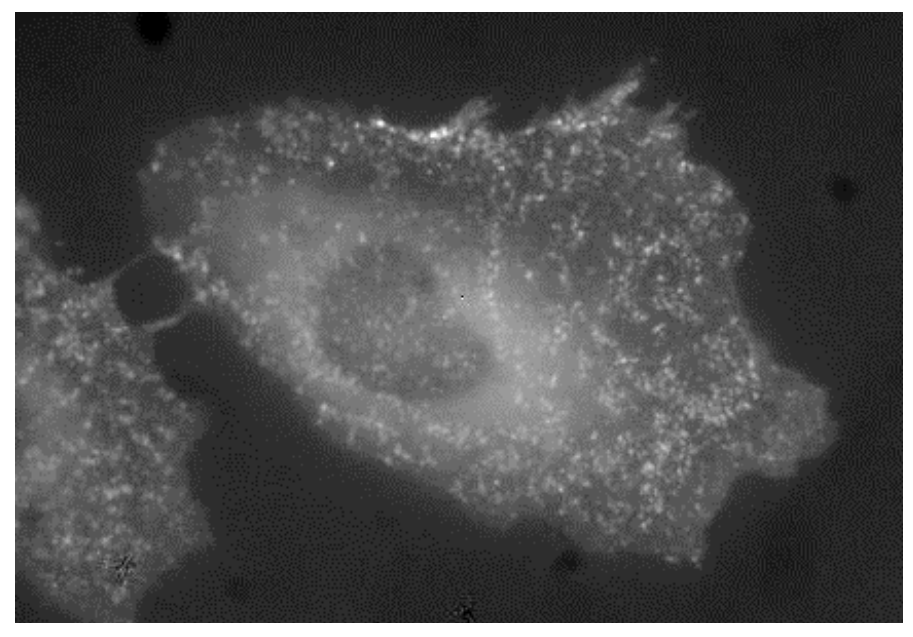

Expression of GFP-myosin VI cargo-binding domain

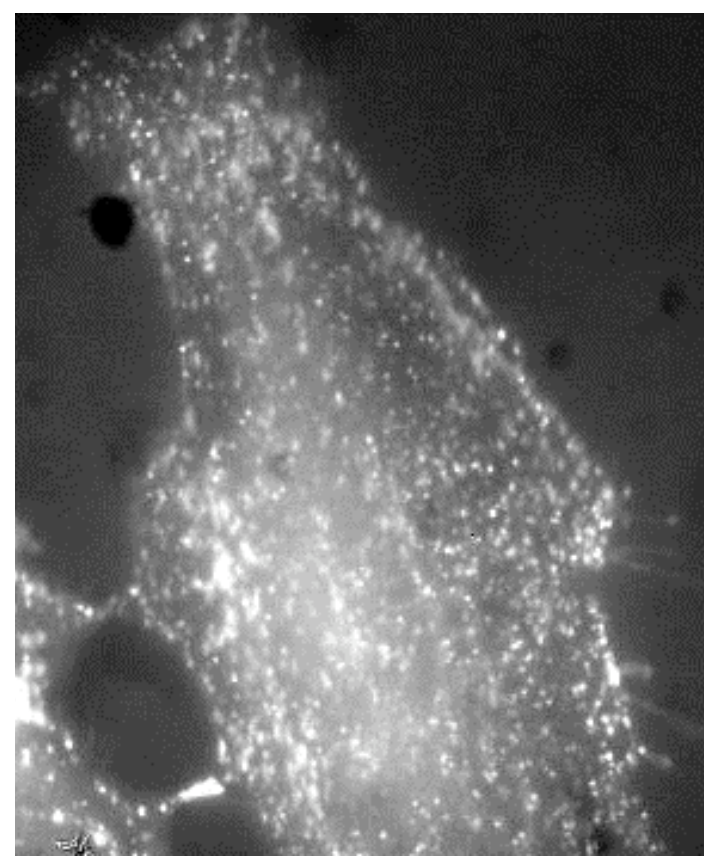




\section{B. CHO cells}

Expression of GFP-myosin VI full length
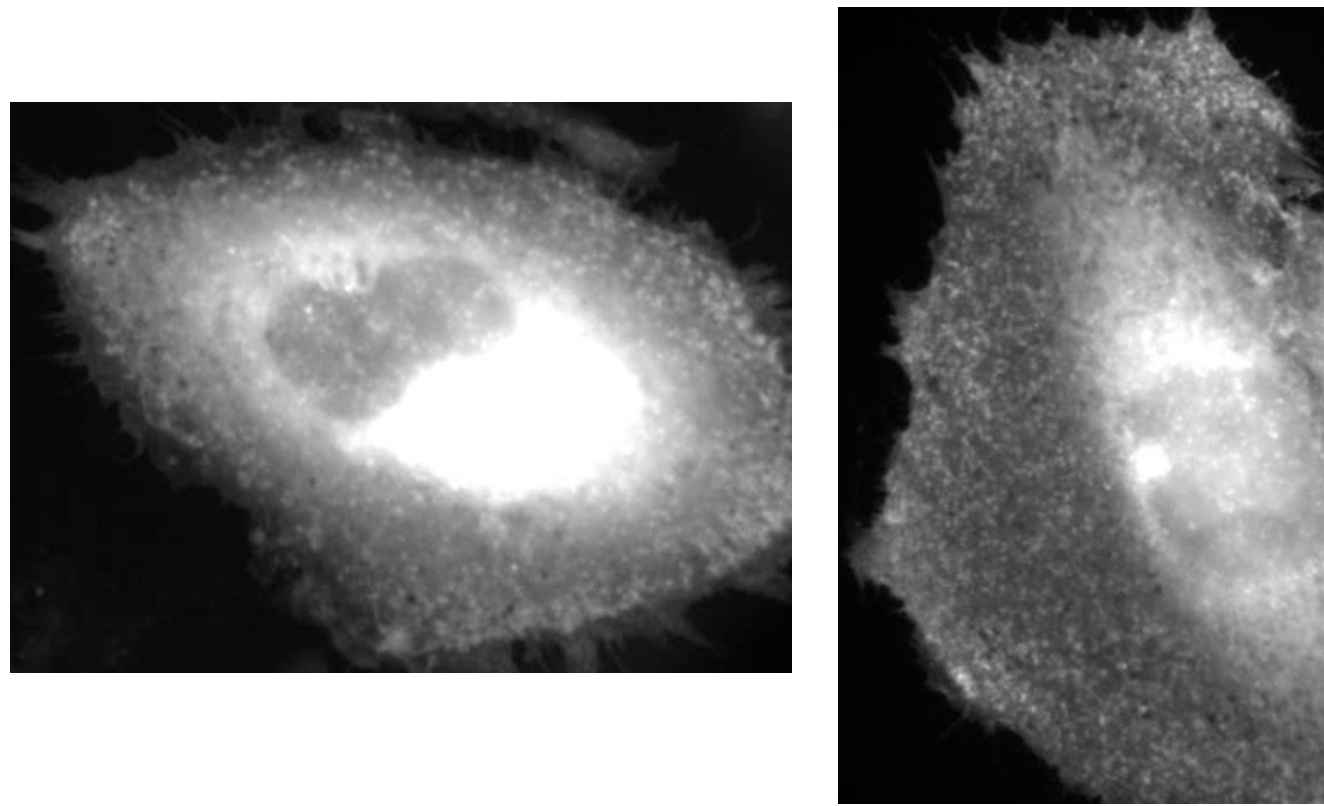

Expression of GFP-myosin VI cargo-binding domain
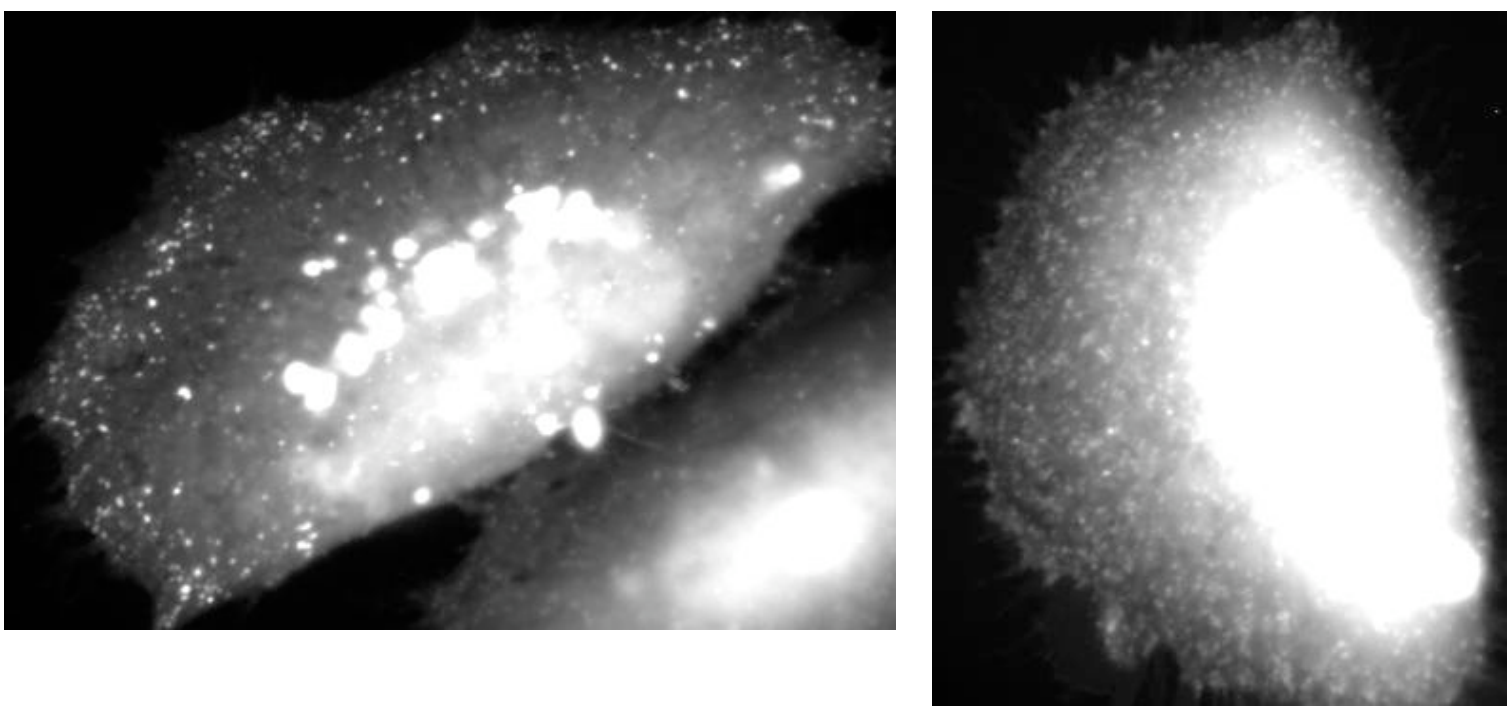


\section{Miscellaneous}

Useful numbers for Cell Culture - from Invitrogen

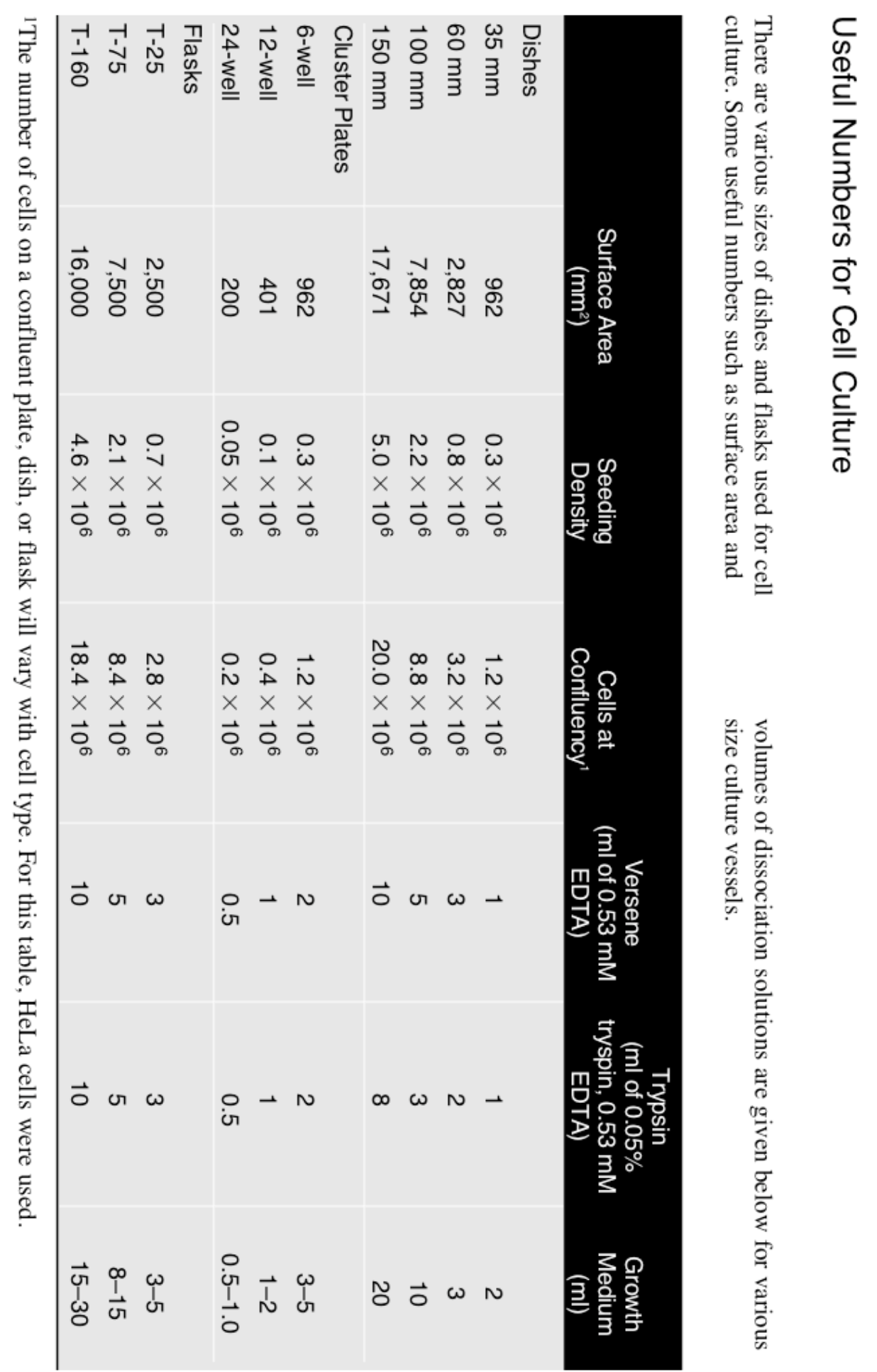

